\title{
Transcolonic Perirectal NOTES Access (PNA): A feasibility study with survival in swine model
}

\author{
ANDRÉ L.A. OLIVEIRA ${ }^{1}$, RICARDO ZORRON ${ }^{2}$, FLAVIO M.M. DE OLIVEIRA ${ }^{3}$, MARCELO B. DOS \\ SANTOS JUNIOR ${ }^{1}$, JUSSARA P. SCHEFFER ${ }^{1}$, MARCELO RIOS ${ }^{4}$ and FERNANDA ANTUNES ${ }^{1}$ \\ ${ }^{1}$ Departamento de Cirurgia Veterinária, Universidade Estadual do Norte Fluminense/ UENF, Av. \\ Alberto Lamego, 2000, Parque Califórnia, 28013-602 Campos dos Goytacazes, RJ, Brazil \\ ${ }^{2}$ Charité Universitätsmedizin Berlin, Campus Virchow Klinikum Klinik für Allgemein, Viszeral- \\ und Transplantationchirurgie, Augustenburger Platz 1, 13353 Berlin, Deutschland \\ ${ }^{3}$ Rua Gavião Peixoto, 70, Cirurgia Videolaparoscópica - Icaraí Corporate, Icaraí, 24230-100 Niterói, RJ, Brazil \\ ${ }^{4}$ Clínica Veterinária-Gávea, Rua Marquês de São Vicente, 170, Gávea, 22451-040 Rio de Janeiro, RJ, Brazil
}

Manuscript received on August 18, 2016; accepted for publication on January 23, 2017

\begin{abstract}
Transrectal access still has some unsolved issues such as spatial orientation, infection, access and site closure. This study presents a simple technique to perform transcolonic access with survival in a swine model series. A new technique for NOTES perirectal access to perform retroperitoneoscopy, peritoneoscopy, liver and lymphnode biopsies was performed in 6 pigs, using Totally NOTES technique. The specimens were extracted transanally. The flexible endoscope was inserted through a posterior transmural incision and the retrorectal space. Cultures of bacteria were documented for the retroperitoneal space and intra abdominal cavity after 14 days. Rectal site was closed using non-absorbable sutures. There was no bowel cleansing, nor preoperative fasting. The procedures were performed in 6 pigs through transcolonic natural orifice access using available endoscopic flexible instruments. All animals survived 14 days without complications, and cultures were negative. Histopathologic examination of the rectal closure site showed adequate healing of suture line and no micro abscesses. The results of feasibility and safety of experimental Transcolonic NOTES potentially brings new frontiers and future wider applications for minimally invasive surgery. The treatment of colorectal, abdominal and retroperitoneal diseases through a flexible Perirectal NOTES Access (PNA) is a promising new approach.
\end{abstract}

Key words: rectal cancer, total mesorectal excision, colorectal surgery, natural orifice surgery, minimally invasive surgery.

\section{INTRODUCTION}

Recently natural orifice surgery has gain supporters as a promising new alternative to incisional and laparoscopic surgery for abdominal procedures. Potential benefits such as avoid surgical incision

Correspondence to: André Lacerda de Abreu Oliveira

E-mail: lacerdavet@uol.com.br

* Contribution to the centenary of the Brazilian Academy of Sciences. complications led to the first successful series of clinical applications, reported in literature, for transvaginal and transgastric natural orifice transluminal endoscopic surgery (NOTES) (Pasricha and Krummel 2009, Sodergreen et al. 2009, Voermans et al. 2010, Zorron et al. 2010a, Fuchs et al. 2013, Katagiri et al. in press., Meillat et al. 2016).

In few recent trials, transcolonic NOTES surgery was performed and the authors suggested 
that the access could be an attractive option for treating colonic and abdominal diseases (Pai et al. 2006, Wilhelm et al. 2007, Ryou et al. 2008, Ryou and Thompson 2008, Bachman et al. 2009, Zorron et al. 2010a, Autorino et al. 2013, Zorron et al. 2014, Katagiri et al. in press). However, there are some technical obstacles to solve before standardization of trancolonic approach, such as the risk of infection, safe entrance in the abdominal cavity and closure of reliable colonic. Based on those issues, our research group developed a new flexible technique to perform a transcolonic procedure in animals. Besides, we also developed a trasncolonic perirectal acces to allow therapy inside abdominal cavity and retroperitoneal space.

Total mesorectal excision (TME) with high lymphadenectomy is the standardized procedure for curative resection of rectal cancer (Heald et al. 1982, Heald and Ryall 1986, Fong et al. 2007, Zorron 2010, Zorron et al. 2012). Besides minimally invasive surgery is been considered as effective as open surgeries to threat a disease (Lujan et al. 2009, Fuchs et al. 2013). A technique developed at our institution and tested in animal model, Perirectal NOTES Access (PNA), was employed to start clinical applications. This study describes the first transcolonic NOTES procedure in an animal model, using flexible endoscopic instruments.

\section{MATERIALS AND METHODS}

The institutional review board for NOTES clinical trials approved this study and all methods were in accordance with the Helsinqui Declaration, revised 1989. Our research team consisted of a multidisciplinary group, counted with a veterinary hospital facility to perform this study. Before the beginning of the trial there were some training, during 10 months, in order to get the group well trained, mostly in spatial orientation, insufflation and instrumental management.
For the trial six pigs weighing from 25 to $40 \mathrm{~kg}$ were submitted to transcolonic flexible endoscopic NOTES retroperitoneoscopy, lymph node biopsies, liver biopsies and abdominal inventory using a flexible 2-channel gastroscope (KarlStorz, Tuttlingen Germany) (Fig. 1). Those animals were observed for a period of 14 days, and intra- and postoperative parameters were documented. The interventional team was composed of a general surgeon, a gastroenterologist and endoscopist, and two veterinarians surgeons.

\section{SURGICAL TECHNIQUE}

The animals were installed in the Lloyd-Davies position under general anesthesia. Antibiotic prophilaxy was performed at induction using $400 \mathrm{mg}$ ciprofloxacin associated with $500 \mathrm{mg}$ metronidazol and continued for three days after procedure. The equipment used was a flexible 2-channel gastroscopy (KarlStorz, Tuttlingen Germany). Before rectal NOTES access, an anuscope was inserted transanally, and the rectum was closed by a circumferencial purse-string suture made with Vicryl 2.0 under direct vision to avoid insufflation of the bowel and to avoid contamination from the proximal colon. The incision on rectal stump was made $2 \mathrm{~cm}$ from the anal verge and to secure these the suture was placed about $4 \mathrm{~cm}$ from the anal verge. After closing the limit of anal resection we proceed with disinfection of the distal rectum using disinfected topic Betadine irrigation.

The anal verge was identified, and a $2.5 \mathrm{~cm}$ posterior incision was performed, using monopolar cautery under direct vision (Fig. 2a). The access orifice was tested by digital exploration, and the colonoscope was inserted directly in the perirectal retroperitoneal space (Fig. 2b).

The Perirectal NOTES Access (PNA) needs an initial low posterior perforation to the anatomic plane between the presacral fascia and the fascia propria, evolving the dissection proximally 


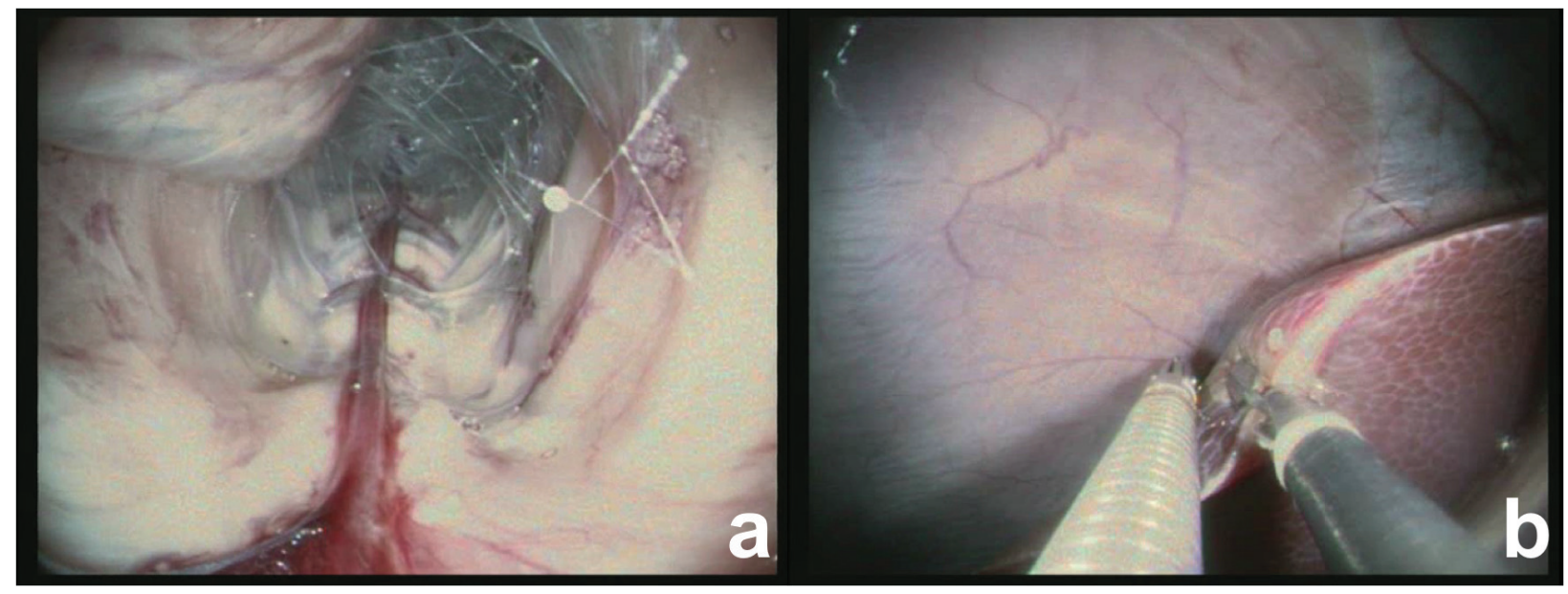

Figure 1 - Transcolonic images of swine models, obtained with a flexible endoscopic. a. NOTES retroperitoneoscopy visualization in swine models. b. Visualization of liver biopsies during transcolonic NOTES in swine models.

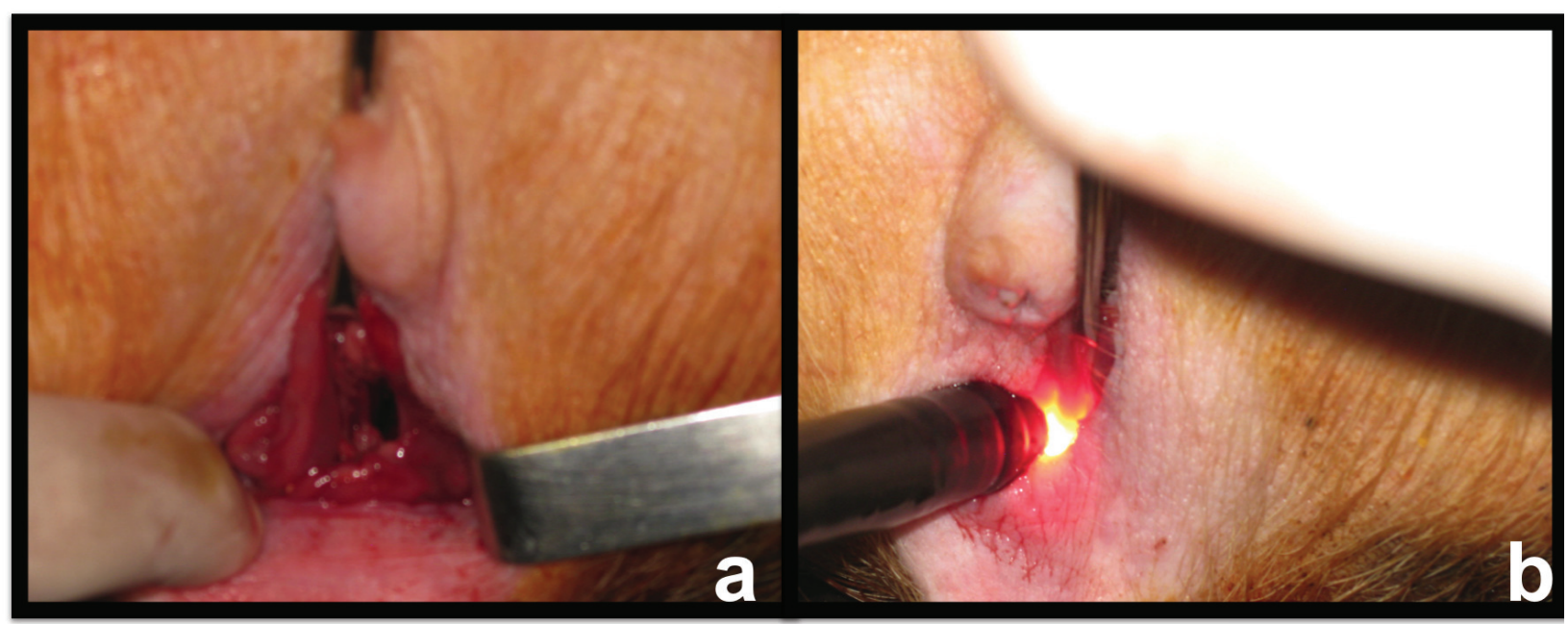

Figure 2 - a. Identification of the anal verge and incision in swine models. b. Insertion of the colonoscope directly into the retroperitoneal space in swine models.

and circumferencially. Afterwards directing the endoscope and insufflating it a blunt dissection was made a blunt preserving fascia as orientation. To complete mesorectal resection an endoscopic monopolar scissors (Apollo Endosurgery, Austin, USA) was progressively used throught the ideal oncologic plane of dissection.

Progression of TME dissection to lateral and anterior aspects was performed using monopolar scissors and blunt dissection, and the abdominal cavity was reached at the left lateral aspect of the dissection. At this point, loss of retropneumoperitonium occurred because there was a leaking to abdominal cavity. Laparoscopic instruments were then used to dissect and liberate the left colon and partially the splenic flexure, and to complete the sigmoid dissection and liberation of the upper aspect of the rectum and sigmoid colon.

Intrarectal Duval graspers grasped the specimen, and the specimen was fully transanally extracted. The resection of the exposed colon was performed using monopolar cutting, and the proximal colon limit was prepared inserting the distal anvil of the circular stapler. The proximal 
colon and the anvil were again reinserted transanally into the cavity. The rectal stump was sectioned transanally in its whole circumference, and a circular closure of the rectal stump was performed using a running suture of 2.0 Prolene to allow transanal introduction of the circular stapler. Transanal stapled anastomosis was performed. Proximal colostomy in the right transverse colon was performed to protect the low anastomosis. Closed drainage of the pelvic dissection and of anastomotic site was installed using a tubular drain. The resected specimen showed adequate mesorectal resection with the preservation of the mesorectal envelope, and a distal margin of $4 \mathrm{~cm}$ from the tumor limits.

\section{RESULTS}

Operative time was $44 \mathrm{~min}$. Compared to preoperative findings, hemoglobin levels and hematocrit $(11.9 \mathrm{mg} / \mathrm{dl}$ and $35.3 \%$ ) had few changes after the procedure on the first postoperative day $(11.1 \mathrm{mg} / \mathrm{dl}$ and $32.3 \%$ respectively). Despite the long operative time, intraoperative blood loss was low (120ml).

The patient recovered uneventfully, and initiated bowel movements and oral liquid diet on the third postoperative day. Antibiotic therapy was continued during hospital stay due to lack of adequate bowel preparation and local contamination of the rectal stump. The patient claimed of transitory paresthesia of both feet due to intraoperative positioning that disappeared after 10 days. Visual analogue pain score showed a level 0 of pain two hours after the procedure, level 0 score on the first postoperative morning, and level 3 on the $7^{\text {th }}$ postoperative day. External aspect of the abdomen showed good result with the avoidance of extraction site. The patient was discharged on the $6^{\text {th }}$ postoperative day, and no infectious complications were recorded until the $15^{\text {th }}$ postoperative day.

\section{DISCUSSION}

In the last few years, surgical community has increased interest in even lesser invasive procedures to diagnose and treat abdominal diseases, after the evolution of laparoscopy (Kalloo et al. 2004, Lima et al. 2010, Fyock et al. 2011, Zheng et al. 2011, Fuchs et al. 2013, Ge et al. 2014, Zorron et al. 2014, Katagiri et al. in press, Meillat et al. 2016). Natural orifice surgery, besides enthusiasm and the promissing potential advantages, didn't signalized superiority in any medical indication over standard surgical therapy yet (Pasricha and Krummel 2009, Sodergreen et al. 2009, Mathews et al. 2010, Zorron et al. 2010b, Kono et al. 2012, Fuchs et al. 2013). Experimental and clinical studies still demonstrate that evolution of technollogy is needed to expand the possibilities of the new field, allowing safety and efficiency of NOTES techniques.

Papers and trials presented on scientific meetings since 2007 described also first clinical human applications of the new method, after IRB approval for human trials on NOTES in different countries. There were 195 human cases worldwide independently reported to date, and other 362 cases enrolled in IMTN NOTES Multicenter Study (Zorron 2009), mostly describing low complication rates. Since Zorrón et al. (2007), Marescaux et al. (2007), Zornig et al. (2007) and Branco Filho et al. (2007) described successful NOTES transvaginal cholecystectomy in early 2007, other groups follow and published their initial clinical results of the techniques, mostly assisted by laparoscopy for retraction or for camera purposes (Forgione et al. 2008, Ramos et al. 2008b, Zorron et al. 2008b, Davila et al. 2009, De Sousa et al. 2009, Decarli et al. 2009, Fischer et al. 2009, Gumbs et al. 2009, Horgan et al. 2009, Noguera et al. 2009, Palanivelu et al. 2009). Transgastric appendectomy was also clinically presented in meetings by Rao and Reddy using available endoscopic instruments since 2005 (Rao et al. 2008), and successful transgastric 
PEG rescue was described by Marks et al. (2007). Transvaginal NOTES appendectomy was first described by Palanivelu et al. (2008) and Ramos et al. (2008a) presented a first series of transvaginal NOTES sleeve gastrectomy. Frequently, procedures as transgastric pancreatic debridement by Seifert et al. (2000), and Transanally Endoscopic Microsurgery (TEM) performed by Bueß et al. (1988) were correctly referred as pioneering NOTES techniques.

Previous clinical work regarding use of natural orifice surgery for cancer surgery was described by Seifert et al. (2000) using a transgastric access to evaluate pancreatic cancer, and Zorron et al. (2008a) by transvaginal approach to perform liver, peritoneal, great omentum and ovarian biopsies to evaluate carcinomatosis. In the former, a transgastric NOTES evaluation showed precision on prevent respectability in 9 of 10 patients. Determination of resectability was decided based on laparoscopic and transgastric NOTES by examiners independent of each other's findings, and demonstrated the feasibility of transgastric endoscopic cavity exploration. In the small series on NOTES surgery for cancer, natural orifice tumor implantation were not yet described, but are a matter of concern in performing oncologic resections.

Whereas most investigators have chosen to gain peritoneal access via a vaginal or an oral transgastric route, few have investigated the transcolonic route (Pai et al. 2006, Wilhelm et al. 2007, Ryou and Thompson 2008, Sporn et al. 2008, Bachman et al. 2009, Katagiri et al. in press). The transcolonic approach has several theoretic advantages over the transgastric route, by eliminating the need for scope retroflection for upper abdominal surgery, allows a more direct access route and closer than a transgastric approach, and the anorectum allows passage of larger-diameter instrumentation and retrieval of larger specimens ${ }^{37}$. Transcolonic and transvaginal extractions of specimens in laparoscopic surgery have been more constantly used in recent years to allow larger organs like spleen, kidney and colon to be retrieved avoiding an abdominal incision. These techniques classified as NOSE (natural orifice specimen extraction) (Palanivelu et al. 2009) showed good results with few complications reported (Breda et al. 1993, Delvaux et al. 1993, Zornig et al. 1994, Abrao et al. 2005, Franklin et al. 2008, Akamatsu et al. 2009, Velhote and Velhote 2009). NOTES Transvaginal colectomy assisted by minilaparoscopy was first described in clinical setting by Lacy et al, naming the technique as MA$\mathrm{NOS}^{46}$ in a patient for sigmoid cancer. Burghardt et al. (2008) reported a case of hybrid transvaginal right colectomy.

Transcolonic NOTES using rigid transanal systems was subject of research in recent experimental and cadaver studies. Whiteford et al showed the feasibility of rigid NOTES sigmoid resection in three cadavers, using transanal endoscopic microsurgery, allowing enbloc lymphadenectomy and transanal retrieval and anastomosis(Whiteford et al. 2007). In their impression, the main obstacles for the use of rigid systems in colorectal surgery are the acute angle created by the sacral promontory and the limited reach of current instruments Sylla et al successfully performed a technique using rigid transanal resection of the colon and sometimes a transgastric flexible access to allow mobilization of the colon, in a set of 14 non-survival and cadaver animal experiment ${ }^{48}$. Leroy et al described a combined technique using flexible and rigid transrectal and flexible transgastric accesses to perform sigmoidectomy in a pig model (Leroy et al. 2009). The technique using the concept of Totally NOTES resulted in survival of all 5 pigs, and no signs of peritonitis or intraabdominal abscess was found either in laparoscopy nor by laparotomy on the 14th postoperative day. The authors pointed the possibility of performing colorectal natural orifice surgery using available instruments. 
Transanally Endoscopic Microsurgery (TEM), developed and described by Buess et al in the early 80 's is currently a minimally invasive alternative for most benign lesions of the rectum, and represent pioneer efforts in the field of natural orifice surgery (Bueß et al. 1988, Delvaux et al. 1993, Zornig et al. 1994, Whiteford et al. 2007, Hazey et al. 2008, Palanivelu et al. 2008, Zorron et al. 2008a). The concept of installing an intrarectal platform to perform colorectal surgery, in currently cases performing truly circumferencial sleeve resections was initially reserved for resection of tumors located below the peritoneal reflection in the extraperitoneal rectum, avoiding perforation into the peritoneal cavity. Resection of tumors in the upper rectum with entry into the suture closure of the peritoneum has recently been described, without increase in infectious postoperative complications (Gavagan et al. 2004).

Total mesorectal resection allied to en bloc lymphadenectomy with high ligation of inferior mesenteric artery is the standard of care of oncologic curative resection of rectal adenocarcinoma. As described by Heald in 1982, a precise plane of dissection allowed improved oncological respectability without tumor cell spillage, improving results and decreasing the indication for abdomino-perineal resection (Heald et al. 1982, Heald and Ryall 1986, Lujan et al. 2009). As evidenced by the present study, an adequate TME with preservation of the mesorectal envelope can be achieved using flexible transcolonic technique. Using the NOTES perirectal access described, radical TME was performed in the opposite direction (from anal to rectosigmoid junction), performed along embryologic fusion planes, beginning the dissection by gaining access to the presacral plane located between the mesorectum and the presacral fascia. Entry and subsequent dissection in this avascular plane using flexible endocopic equipment was more hazardous than formal laparoscopy due to limited instrumentation, but retropneumoperitoneum improved the exposure and dissection inside the anatomic plane.

Naturally, transrectal access raises concerns of infection control and still requires the need for secure closure of the colorectum (Rattner and Kaloo 2006, Kantsevoy 2008, Bachman et al. 2009). However, a low entry point as described in this study and using a retroperitoneal tunnel instead of puncturing the rectosigmoid junction, previously closing the proximal rectum, allows for a relative isolated field that can be adequately disinfected, avoiding bowel preparation. Despite the need of a colorectal perforation, choosing the entry point in the exact planned line of anastomosis minimizes the fear of unnecessary viscerotomy. The original transcolonic perirectal NOTES access allows to a low and safe perforation of the rectum, with ease and safe of entrance and closure under direct view. Retroperitoneal insuflation and retroperitoneoscopy also represents original access to perform transcolonic retroperitoneal lymphnode biopsies and even pancreatic, renal or adrenal surgery. The perirectal NOTES access promotes a fast and easy access to abdominal cavity, avoiding the need of expensive technology for the access. In terms of surgical philosophy, transcolonic colorectal surgery seems to make sense, rather than trespassing the colon to reach other organs. Standard endoscopy and future flexible platforms are undoubtely a helpful technology to perform transcolonic NOTES techniques.

The described new NOTES access for rectal cancer adhere to the principles of oncologic resection and opens a wide range of possibilities of future applications of transcolonic NOTES for colorectal surgery. Despite advantages over existing laparoscopic and open methods cannot be distinguished in this early beginning of the concept, flexible transorificial performance of colorectal operations seems promising. 


\section{REFERENCES}

ABRAO MS, SAGAE UE, PODGAEC M AND DIAS JR JA. 2005. Treatment of rectosigmoid endometriosis by laparoscopically assisted vaginal rectosigmoidectomy. Int J Gynaecol Obstet 91(1): 27-31.

AKAMATSU H, OMORI T, OYAMA T, TORI M, UESHIMA S, NAKAHARA M, ABE AND NISHIDA T. 2009. Totally laparoscopic sigmoid colectomy: a simple and safe technique for intracorporeal anastomosis. Surgical Endoscopy.

AUTORINO R ET AL. 2013. Natural orifice transluminal endoscopic surgery (NOTES): where are we going? A bibliometric assessment. BJU Int 111(1): 11-16.

BACHMAN SL, SPORN S, FURRER JL, ASTUDILLO JA, CALALUCE R, MCINTOSH MA, MIEDEMA BW AND THALER K. 2009. Endoscopic colotomy closure for natural orifice surgery using a T-fastener prototype in comparison to conventional laparoscopic suture closure. Surg Endosc 23: 1854-1859.

BRANCO FILHO AJ, NODA RW, KONDO W, KAWAHARA N, RANGEL M AND BRANCO AW. 2007. Initial experience with hybrid transvaginal cholecystectomy. Gastrointest Endosc 66(6): 1245-1248.

BREDA G, SILVESTRE P, GIUNTA A, XAUSA D, TAMAI A AND GHERARDI L. 1993. Laparoscopic nephrectomy with vaginal delivery of the intact kidney. Eur Urol 24(1): 116-117.

BUES G, KIPFMÜLLER K, IBALD R, HEINTZ A, HACK D, BRAUNSTEIN S, GABBERT H AND JUNGINGER T. 1988. Clinical results of transanal endoscopic microsurgery. Surg Endosc 2(4): 245-250.

BURGHARDT J, FEDERLEIN M, MÜLLER V, BENHIDJEB T, ELLING D AND GELLERT K. 2008. Minimal invasive transvaginal right hemicolectomy: report of the first complex NOS (natural orifice surgery) bowels operation using a hybrid approach. Zentralbl Chir 133(6): 574-576.

DAVILA F, TSIN DA, DOMINGUEZ G, DAVILA U, JESÚS R AND ARTECHE AGD. 2009. Transvaginal cholecystectomy without abdominal ports. JSLS 13(2): 213-216.

DE SOUSA LH, DE SOUSA JAG, DE SOUSA FILHO LH, DE SOUSA MM, DE SOUSA VM, DE SOUSA APM AND ZORRON R. 2009. Totally NOTES (T-NOTES) transvaginal cholecystectomy using two endoscopes: preliminary report. Surg Endosc 23(11): 2550.

DECARLI L, ZORRON R, BRANCO A, LIMA FC, TANG M, PIONEER SR, SANSEVERINO JI, MENGUER R, BIGOLIN AV AND GAGNER M. 2009. New hybrid approach for NOTES transvaginal cholecystectomy: Preliminary clinical experience. Surgical Innovation 16(20): 181-186.
DELVAUX G, DEVROEY P, WAELE BD AND WILLEMS G. 1993. Transvaginal removal of gallbladders with large stones after laparoscopic cholecystectomy. Surg Laparosc Endosc Percutan Tech 3(4): 307-309.

FISCHER LJ, JACOBSEN G, WONG B, THOMPSON K, BOSIA J, TALAMINI MAND HORGAN S. 2009. NOTES laparoscopic-assisted transvaginal sleeve gastrectomy in humans--description of preliminary experience in the United States. Surg Obes Relat Dis 5(5): 633-636.

FONG DG, PAI RD AND THOMPSON CC. 2007. Transcolonic endoscopic abdominal exploration: a NOTES survival study in a porcine model. Gastrointest Endosc 65(2): 312-318.

FORGIONE A, MAGGIONI D, SANSONNA F, FERRARI C, LERNIA SD, CITTERIO D, MAGISTRO C, FRIGERIO L AND PUGLIESE R. 2008. Transvaginal endoscopic cholecystectomy in human beings: preliminary results. Surg Laparosc Endosc Percutan Tech 18(3): 345-351.

FRANKLIN M, KELLEY H, BRESTAN L, PORTILLO G AND TORRES J. 2008. Transvaginal extraction of the specimen after total laparoscopic right hemicolectomy with intracorporeal anastomosis. Surg Laparosc Endosc Percutan Tech 18: 294-298.

FUCHS KH, MEINING A, VON RENTELN D, FERNANDEZ-ESPARRACH G, BREITHAUPT W, ZORNIG C AND LACY A. 2013. Euro-NOTES Status Paper: from the concept to clinical practice. Surg Endosc 27(5): 1456-1467.

FYOCK CJ, FORSMARK CE AND WAGH MS. 2011. Endoscopic Management of Intraoperative Small Bowel Laceration During Natural Orifice Translumenal Endoscopic Surgery: A Blinded Porcine Study. Surg Laparosc Endosc Percutan Tech 21(6): 525-530.

GAVAGAN JA, WHITEFORD MH AND SWANSTROM LL. 2004. Full-thickness intraperitoneal excision by transanal endoscopic microsurgery does not increase short-term complications. Am J Surg 187: 630-634.

GE N ET AL. 2014. EUS assisted transmural cholecystogastrostomy fistula creation as a bridge for endoscopic internal gallbladder therapy using a novel fully covered metal stent. BMC Gastroenterology 14: 164.

GUMBS AA, FOWLLER D, MILONE L, EVANKO JC, UDE AO, STEVENS P AND BESSLER M. 2009. Transvaginal natural endoscopic surgery cholecystectomy: early evolution of the technique. Ann Surg 249(6): 908-912.

HAZEY JW, NARULA VK, RENTON DB, REAVIS KM, PAUL CM, HINSHAW KE, MUSCARELLA P, ELLISON EC AND MELVIN WS. 2008. Natural orifice transgastric endoscopic peritoneoscopy in humans: initial clinical trial. Surg Endosc 22: 16-20.

HEALD RJ, HUSBAND EM AND RYALL RD. 1982. The mesorectum in rectal cancer surgery: the clue to pelvic recurrence? Br J Surg 69: 613-616. 
HEALD RJ AND RYALL RD. 1986. Recurrence and survival after total mesorectal excision for rectal cancer. Lancet 1 : 1479-1482.

HORGAN S ET AL. 2009. Natural orifice surgery: initial clinical experience. Surg Endosc 23(7): 1512-1518.

KALLOO AN, SINGH VK, JAGANNATH BS, NIIYAMA H, HILL SL, VAUGHN CA, MAGEE CA AND KANTSVOY SV. 2004. Randomized clinical trial comparing laparoscopic and open surgery in patients with rectal cancer. Gastrointest Endosc 60(1): 287-292.

KANTSEVOY SV. 2008. Infection Prevention in NOTES. Gastrointest Endosc Clin N Am 18: 291-296.

KATAGIRI T, OTSUKA Y, HORGAN S, SANDLER BJ, JACOBSEN GR, COKER AM, TSUCHIYA M, MAEDA AND KANEKO H. in press. Feasibility and Technique for Transvaginal Natural Orifice Transluminal Endoscopic Surgery Liver Resection: A Porcine Model. Surg Laparosc Endosc Percutan Tech 27(1).

KONO Y ET AL. 2012. Transrectal peritoneal access with the submucosal tunnel technique in NOTES: a porcine survival study. Surg Endosc 27(1): 278-285.

LEROY J, CAHILL RA, PERETTA S, FORGIONE A, DALLEMAGNE B AND MARESCAUX J. 2009. Natural orifice translumenal endoscopic surgery (NOTES) applied totally to sigmoidectomy: an original technique with survival in a porcine model. Surg Endosc 23(24-30): 24.

LIMA E, ROLANDA C, AUTORINO R AND CORREIAPINTO J. 2010. Experimental foundation for natural orifice transluminal endoscopic surgery and hybrid natural orifice transluminal endoscopic surgery. BJU Int 106(6b): 913-918.

LUJAN J, VALERO G, HERNANDEZ Q, SANCHEZ A, FRUTOS MD AND PARRILLA P. 2009. Randomized clinical trial comparing laparoscopic and open surgery in patients with rectal cancer. Br J Surg 96(982-989): 982.

MARESCAUX J, DALLEMAGNE B, PERRETTA S, WATTIEZ A, MUTTER D AND COUMAROS D. 2007. Surgery without scars: Report of transluminal cholecystectomy in a human being. Arch Surg 142(9): 823-826.

MARKS JM, PONSKY JL, PEARL JP AND MCGEE MF. 2007. PEG rescue: a practical NOTES technique. Surg Endosc 21(5): 816-819.

MATHEWS JC ET AL. 2010. Early Healing of Transcolonic and Transgastric Natural Orifice Transluminal Endoscopic Surgery Access Sites. J Am Coll Surg 210(4): 480-490.

MEILLATH, DE CHAISEMARTIN C, POIZAT F, BORIES E, FARA R, DELPERO JR AND LELONG B. 2016. Combined NOTES total mesorectal excision and single-incision laparoscopy principles for conservative proctectomy: a single-centre study. Tech Coloproctol, p. $1-9$.
NOGUERA J, DOLZ C, CUADRADO A, OLEA J, VILELLA A AND MORALES R. 2009. Hybrid transvaginal cholecystectomy, NOTES, and minilaparoscopy: analysis of a prospective clinical series. Surg Endosc 23: 876-881.

PAI RD, FONG DG, BUNDGA ME, ODZE RD, RATTNER DW AND THOMPSON CC. 2006. NOTES and other emerging trends in gastrointestinal endoscopy and surgery: The change that we need and the change that is real. Gastrointest Endosc 64: 428-434.

PALANIVELU C, RAJAN PS, RANGARAJAN M, PRASAD M, KALYANAKUMARI V, PARTHASARATHI R AND SENTHILNATHAN P. 2009. Transvaginal endoscopic cholecystectomy in humans: preliminary report of a case series. Am J Gastroenterol 104(4): 843-847.

PALANIVELU C, RANGARAJAN M, JATEGAONKAR PA AND ANAND NV. 2008. An innovative technique for colorectal specimen retrieval: a new era of "natural orifice specimen extraction" (N.O.S.E). Dis Colon Rectum 51(7): 1120-1124.

PASRICHA PJ AND KRUMMEL TM. 2009. NOTES and other emerging trends in gastrointestinal endoscopy and surgery: The change that we need and the change that is real. Am J Gastroenterol 104: 2384-2386.

RAMOS AC, MURAMAKI A, NETO MG, GALVÃO MS, SILVA AC, CANSECO EG AND MOYSES Y. 2008b. Transvaginal video-assisted cholecystectomy: first series. Endoscopy 40(7): 572-575.

RAMOS AC, ZUNDEL N, NETO MG AND MAALOUF M. 2008a. Human hybrid NOTES transvaginal sleeve gastrectomy: initial experience. Surg Obes Relat Dis 4(5): 660-663.

RAO GV, REDDY DN AND BANERJEE R. 2008. NOTES: Human Experience. Gastrointest Endosc Clin N Am 18: 361-370.

RATTNER D AND KALOO A. 2006. ASGE/SAGES Working Group on Natural Orifice Translumenal Endoscopic Surgery. Surg Endosc 20(329-333): 329.

RYOU M, FONG DG, PAI RD, SAUER J AND THOMPSON CC. 2008. Evaluation of a novel access and closure device for NOTES applications: a transcolonic survival study in the porcine model (with video). Gastrointest Endosc 67(6): 964-969.

RYOU M AND THOMPSON CC. 2008. Techniques for transanal access to the peritoneal cavity. Gastrointest Endosc Clin N Am 18: 245-260.

SEIFERT H, WEHRMANN T, SCHMITT T, ZEUZEM S AND CASPARY WF. 2000. Retroperitoneal endoscopic debridement for infected peripancreatic necrosis. Lancet 356(9230): 653-655.

SODERGREEN MH, CLARCK J, ATHANASIOU T, TEARE J, YANG GZ AND DARZI A. 2009. Natural orifice translumenal endoscopic rurgery: critical appraisal of 
applications in clinical practice. Surg Endosc 23(4): 680687.

SPORN E, BACHMAN SL, MIEDEMA BW, LOY TS, CALALUCE R AND THALER K. 2008. Endoscopic colotomy closure for natural orifice surgery using a T-fastener prototype in comparison to conventional laparoscopic suture closure. Gastrointest Endosc 68(4): 724-730.

VELHOTE MCP AND VELHOTE CEP. 2009. Treatment of rectosigmoid endometriosis by laparoscopically assisted vaginal rectosigmoidectomy. Surg Laparose Endosc Percutan Tech 19(2): 255-257.

VOERMANS RP, FAIGEL DO, VAN BERGE HENEGOUWEN MI, SHEPPARD B AND FOCKENS P. 2010. Comparison of transcolonic NOTES and laparoscopic peritoneoscopy for the detection of peritoneal metastases. Endoscopy 42(11): 904-909.

WHITEFORD M, DENK EM AND SWANSTROM L. 2007. Feasibility of radical sigmoid colectomy performed as natural orifice translumenal endoscopic surgery (NOTES) using transanal endoscopic microsurgery. Surg Endosc 21(1870-1874): 1870.

WILHELM D, MEINING A, DELIUS SV, FIOLKA A, CAN S, WEYHERN CHV, SCHNEIDER A AND FEUSSNER H. 2007. An innovative, safe and sterile sigmoid access (ISSA) for NOTES. Endoscopy 39: 401-406.

ZHENG YZ ET AL. 2011. An experimental study of betadine irrigation for preventing infection during the natural orifice transluminal endoscopic surgery (NOTES) procedure. J Dig Dis 12(3): 217-222.

ZORNIG C, EMMERMAN A, WALDENFELS HAV AND FELIXMULLER C. 1994. Colpotomy for specimen removal in laparoscopic surgery. Chirurg 65(10): 883-885.

ZORNIG C, EMMERMANN A, WALDENFELS HAV AND MOFID H. 2007. Laparoscopic cholecystectomy without visible scar: combined transvaginal and transumbilical approach. Endoscopy 39(10): 913-915.

ZORRON R. 2009. Techniques of transvaginal access for NOTES. Tech Gastrointest Endosc 11(2): 75-83.

ZORRON R. 2010. Natural orifice surgery applied for colorectal diseases. World J Gastrointest Surg 2(2): 35-38.

ZORRON R, COELHO D, FLACH L, LEMOS FB, MOREIRA MS, OLIVEIRA OS AND BARBOSA AM. 2010a. Cirurgia por orifícios naturais transcolônica: acesso NOTES peri-retal (PNA) para excisão mesoretal total. Rev Bras Coloproct 30: 14-22.

ZORRÓN R, FILGUEIRAS M, MAGGIONI LC, POMBO L, LOPES CARVALHO G AND LACERDA OLIVEIRA A. 2007. NOTES Transvaginal Cholecystectomy: Report of the First Case. Surg Innov 14(4): 279-283.

ZORRON R, MAGGIONI LC, POMBO L, OLIVEIRA AL, CARVALHO GL AND FILGUEIRAS M. 2008b. NOTES Transvaginal cholecystectomy: Preliminary clinical application. Surg Endosc 22(2): 542-547.

ZORRON R. ET AL. 2010b. International Multicenter Trial on Clinical Natural Orifice Surgery-NOTES IMTN Study: Preliminary Results of 362 Patients. Surg Innov 17(2): 142-158.

ZORRON R, PHILLIPS HN, COELHO D, FLACH L, LEMOS FB AND VASSALLO RC. 2012. Perirectal NOTES Access: "Down-to-Up" Total Mesorectal Excision for Rectal Cancer. Surg Innov 19(1): 11-19.

ZORRON R, PHILLIPS H, WYNN G, GALVAO NETO M, COELHO D AND VASSALLO R. 2014. "Down-to-Up" transanal NOTES Total mesorectal excision for rectal cancer: Preliminary series of 9 patients. J Minim Access Surg 10(3): 144-150.

ZORRON R, SOLDAN M, FILGUEIRAS M, MAGGIONI LC, POMBO L AND OLIVEIRA AL. 2008a. NOTES Transvaginal for cancer diagnostic staging: Preliminary clinical application. Surg Innov 15(3): 161-165. 